\title{
Chlorophyll and carotenoid content of wheat (Triticum aestivum L.) seedlings under heat stress as affected by trehalose application
}

\author{
Aparjot Kaur* and S. K. Thind \\ Department of Botany, Punjab Agricultural University, Ludhiana-141004 (Punjab), INDIA \\ *Corresponding author. E-mail: aparjotranu@gmail.com
}

Received: June 12, 2016; Revised received: October 24, 2016; Accepted: August 5, 2017

\begin{abstract}
Presently, chlorophyll and carotenoid contents were evaluated under control $\left(25 \pm 2^{\circ} \mathrm{C}\right)$, heat stress $\left(35 \pm 2^{\circ} \mathrm{C}\right.$ and $\left.40 \pm 2^{\circ} \mathrm{C}\right)$ and interactive effect of heat stress and trehalose in six wheat (Triticum aestivum L.) genotypes (HD2967, PBW175, C306, PBW343, PBW621 and PBW590). Trehalose an osmoprotectant, at concentration of $1 \mathrm{mM}$ and $1.5 \mathrm{mM}$ was applied at 7 days after sowing (DAS) followed by heat stress of $35 \pm 2^{\circ} \mathrm{C}$ (moderate) and $40 \pm 2^{\circ} \mathrm{C}$ (severe) on 8DAS for 4 and8 hours. As chloroplast thylakoid membranes, are highly vulnerable to heat stress, the chlorophyll content decreased with increased temperature stress in all selected genotypes. Heat stress significantly reduced $(P<0.05)$ the carotenoid content in all genotypes. Severe heat stress $(8$ hours) more adversely affected these mentioned parameters. The application of Trehalose @ 1.5mM as compared with $1 \mathrm{mM}$ concentration was found more effective to ameliorate the adverse effect of heat stress on chlorophyll and carotenoid contents to sustain photosynthetic process.
\end{abstract}

Keywords: Heat stress, Photosynthetic pigments, Trehalose, Wheat

\section{INTRODUCTION}

All over the world wheat i.e. Triticum aestivum L. is an necessary cereal crop. In the form of various products wheat is used as staple food. Global wheat supplies are predicted remain commodious in 2016/17 marketing season. Although below the 2015 record, world wheat production in 2016 is to outstrip utilization for the fourth consecutive season, boosting world stocks to a 15 year high. World wheat utilization is seen to decline slightly mostly because of reduced feed use (FAO 2016). It has been found that wheat contain the higher value of vegetable protein in the food of human beings, as it contains higher content of proteins and amino acids than the other major cereals like maize rice (NPCS board, 2012).

As heat stress or temperature stress is described as increase in temperature up to a threshold level for a particular interval of time that cause the unrecoverable harm to the plant or crop growth and development. A sudden rise in temperature basically above $10-15^{\circ} \mathrm{C}$ is consider heat shock or heat stress (Wahid et al., 2007). Due to massive rise in the population the requirement or desire for wheat has been also increased than the previous times, but its yield or harvest decreased due to the environmental stress. Extreme or late temperature stress during the grain filling period of normal as well as delayed planted wheat is the large abiotic stress that severely reducing wheat yield (Khan et al., 2007). Unstable or stable heat stress causes various changes in morpho-anatomical, biochemical and physiological modifications in wheat, that severely affect the crop growth and development. Heat stress violently decreased both quantity and quality of wheat (Wardlaw et al., 2002, Altenbach et al., 2003, Dupont et al., 2006).

Trehalose is a resolveable, non-reducing disaccharide of glucose. Three isomers exist: $\alpha, \alpha$-trehalose, $\alpha, \beta$ trehalose and $\beta, \beta$ - trehalose. Of these, only $\alpha, \alpha$ trehalose (1-O- ( $\alpha$-Dglucopyranosyl) $\alpha$-glucopyranosi $\mathrm{de})$ is found in biological material. It is present in a huge variety of organisms and can serve as reserve of carbohydrate and as a protectant in response to different environmental stress factors. Trehalose is known to protect biological membranes and macromolecules. Its stockpilling has been implicated in permit crops to indulge stress, including heat-stress. Trehalose does protect against desiccation in certain specialized resurrection plants. Gomez et al., 2011 described the discovery of trehalose metabolism in the recent years has pointed out the importance of trehalose biosynthesis in stress responses in plants. Therefore, a primary aim and the significance of this work was to determine the role of trehalose, whether exogenous application of trehalose helps to protect and maintain the chlorophyll and carotenoid content from the destructive effect of heat stress when wheat seedlings exposed to different $\left(35 \pm 2^{\circ} \mathrm{C}\right.$ and $\left.40 \pm 2^{\circ} \mathrm{C}\right)$ levels of heat stress.

\section{MATERIALS AND METHODS}

Plant material: Six genotypes of wheat (T. aestivum 
L.) viz. HD 2967, C306, PBW621, PBW590, PBW343 and PBW175 were obtained from Department of Plant Breeding and Genetics (PAU) and used for studies related to chlorophyll and carotenoid content under control and different heat stress levels. Statistical Analysis: Analysis of variance (ANOVA), critical difference at $5 \%$ level of significance $(\mathrm{P}<0.05 \%)$ was used for the data analysis.

With a view of assess the effect of heat stress on above stated parameters, only healthy seeds of six genotypes of wheat were used in experiments. Seeds were surface sterilized with 0.1 per cent mercury chloride for 2-3 min. to avoid any kind of mycosis during seed germination. Petri plates were sterilized in oven at $100^{\circ} \mathrm{C}$ for 1 hour. Ordinary blotting papers were used in Petri dishes and were autoclaved before use. Twenty seeds were sown in each Petri-dish lined with circular blotting paper and incubated at $25 \pm 2^{\circ} \mathrm{C}$ temperature. On seventh DAS trehalose $(1 \mathrm{mM}$ and $1.5 \mathrm{mM})$ application was given followed by heat stress, incubated at $35^{\circ} \mathrm{C}$ and $40^{\circ} \mathrm{C}$, for $8 \mathrm{hrs}$. Controlled Petri-dishes were placed in an BOD in which heat was maintained at $25^{\circ} \mathrm{C}$.

$\mathrm{T} 1$ - control at $25^{\circ} \mathrm{C}$, T2-T1+(tre- $\left.1 \mathrm{mM}\right)$, T3-T1+(tre$1.5 \mathrm{mM})$, T4- at $35^{\circ} \mathrm{C}$, T5-T4+(tre- $\left.1 \mathrm{mM}\right)$, T6-T4+(tre$1.5 \mathrm{mM}), \mathrm{T} 7-$ at $40^{\circ} \mathrm{C}, \mathrm{T} 8-\mathrm{T} 7+($ tre $-1 \mathrm{mM}), \mathrm{T} 9-\mathrm{T} 7+($ tre$1.5 \mathrm{mM})$

Chlorophyll content and carotenoid content: Chlorophyll content and carotenoid contentwas determined by method as followed by Hiscox and Isrealstam (1979).

The photosynthetic pigments from the wheat leaves by placing the $100 \mathrm{~g}$ of fresh leaves used in the photosynthesis and reflectance measurements in $5 \mathrm{ml}$ of the dimethyl sulfoxide (DMSO) and extracting for $12 \mathrm{~h}$ in the dark. The concentration of the extracted pigments was calculated by recording the absorbance values at 665,645 and $480 \mathrm{~nm}$.

$\mathrm{Chl} \mathrm{a}=12.19(\mathrm{OD} 665)-3.45(\mathrm{OD} 645) \times \mathrm{V} / 1000 \mathrm{xW}$

$\mathrm{Chl} b=21.99(\mathrm{OD} 645)-5.32(\mathrm{OD} 665) \times \mathrm{V} / 1000 \mathrm{xW}$

Total Chl $=20.2(\mathrm{OD} 480)+8.02($ OD665) $\mathrm{x}$ $\mathrm{V} / 1000 \times \mathrm{W}$
Carotenoids $=(O D 480)+0.114($ OD665 $)-0.638($ OD645 $)$ where, $\mathrm{OD}_{663}=\mathrm{OD}$ at $663 \mathrm{~nm} ; \mathrm{OD}_{645}=\mathrm{OD}$ at $645 \mathrm{~nm}$; $\mathrm{OD}_{480}=\mathrm{OD}$ at $480 \mathrm{~nm} ; \mathrm{V}=$ Total volume of solution made; $\mathrm{W}=$ Weight of sample $(\mathrm{g})$ taken

The chlorophyll and carotenoid contents were expressed as $\mathrm{mg} \mathrm{chl} \mathrm{g}^{-1}$ fresh weight.

\section{RESULTS AND DISCUSSION}

Chlorophyll content: During the present study six genotypes of wheat (T.aestivum L.) were exposed to varying levels of heat stress $\left(35 \pm 2^{\circ} \mathrm{C}\right.$ and $\left.40 \pm 2^{\circ} \mathrm{C}\right)$ under laboratory conditions (Table 1-6)) and contents of chlorophyll a, b and total were estimated. The chl a content was in range of 0.598 to 0.646 and $\mathrm{chl} \mathrm{b}$ in range of 0.312 to 0.432 in control. The contents of total chlorophyll varied significantly $(\mathrm{P}<0.05)$ all treatments in all the wheat genotypes studied presently and was recorded more in PBW621 and HD2967 genotypes and least in PBW590. Under severe heat stress i.e. $40 \pm 2^{\circ} \mathrm{C}$ for 8 hours duration chlorophyll a value was recorded more in PBW621 genotype and chl b was more in HD2967 and PBW621 genotype. These results were similar to that of Gautam et al. (2016) as heat stress decreased the chlorophyll a content in the durum wheat genotypes. Khan et al. (2015) also observed that heat stress significantly reduced chl a and chl $b$ contents of wheat genotypes similar to that of Ahmed and Hassan (2011) and Kumar et al. (2012).Presently, it has been also recorded that in all the studied genotypes the chlorophyll content decreased with increased temperature stress. Shirdelmoghanloo (2016) also observed that there was positive correlation between heat stress and chlorophyll degradation or chlorophyll loss. Chloroplast thylakoid membranes, are highly vulnerable to heat stress. High temperatures led not only to disintegration of the lipid bilayer (Losa et al., 2004), but also to damage of the oxygen- evolving complex of photosystem 2 (Komayama et al., 2007). There is an inverse correlation between growth temperature and membrane saturation level. Changes in lipid-protein interactions are thought to play a major role in heat-induced increase in

Table 1. Effect of trehalose on chlorophyll a $\left(\mathrm{mg} \mathrm{gm}^{-1}\right.$ fresh weight) content of wheat genotypes under heat stress (4hrs) of $35 \pm 2^{\circ} \mathrm{C}$ and $40 \pm 2^{\circ} \mathrm{C}$

\begin{tabular}{|c|c|c|c|c|c|c|}
\hline \multirow{2}{*}{ Treatments } & \multicolumn{6}{|c|}{ Genotypes } \\
\hline & HD2967 & PBW175 & C306 & PBW343 & PBW621 & PBW590 \\
\hline $\mathrm{T} 1-\mathrm{Control}$ at $25^{\circ} \mathrm{C}$ & 0.646 & 0.628 & 0.643 & 0.632 & 0.646 & 0.598 \\
\hline $\mathrm{T} 2-\mathrm{T} 1+($ tre-1mM) & 0.647 & 0.638 & 0.644 & 0.636 & 0.646 & 0.598 \\
\hline $\mathrm{T} 3-\mathrm{T} 1+($ tre- $1.5 \mathrm{mM})$ & 0.649 & 0.639 & 0.649 & 0.639 & 0.649 & 0.599 \\
\hline $\mathrm{T} 4-$ at $35^{\circ} \mathrm{C}$ & 0.632 & 0.622 & 0.628 & 0.628 & 0.633 & 0.596 \\
\hline T5-T4+(tre-1mM) & 0.634 & 0.626 & 0.629 & 0.629 & 0.638 & 0.596 \\
\hline T6-T4+(tre-1.5mM) & 0.638 & 0.631 & 0.631 & 0.630 & 0.642 & 0.599 \\
\hline $\mathrm{T} 7$ - at $40^{\circ} \mathrm{C}$ & 0.618 & 0.598 & 0.611 & 0.599 & 0.617 & 0.566 \\
\hline T8-T7+(tre-1mM) & 0.619 & 0.598 & 0.613 & 0.614 & 0.619 & 0.572 \\
\hline T9-T7+(tre-1.5mM) & 0.626 & 0.600 & 0.614 & 0.615 & 0.621 & 0.578 \\
\hline CD $5 \%$ & \multicolumn{6}{|c|}{$\mathrm{V}=0.077, \mathrm{~T}=0.094, \mathrm{~V} \times \mathrm{T}=0.232$} \\
\hline
\end{tabular}


Table 2. Effect of trehalose on chlorophyll a ( $\mathrm{mg} \mathrm{gm}^{-1}$ fresh weight) content of wheat genotypes under heat stress ( $\left.8 \mathrm{hrs}\right)$ of $35 \pm 2^{\circ} \mathrm{C}$ and $40 \pm 2^{\circ} \mathrm{C}$.

\begin{tabular}{lcccccc}
\hline \multirow{2}{*}{ Treatments } & \multicolumn{7}{c}{ Genotypes } \\
\cline { 2 - 7 } & HD2967 & PBW175 & C306 & PBW343 & PBW621 & PBW590 \\
\hline T1-Control at 25 ${ }^{\circ} \mathrm{C}$ & 0.641 & 0.622 & 0.632 & 0.631 & 0.645 & 0.598 \\
T2-T1+(tre-1mM) & 0.646 & 0.626 & 0.638 & 0.636 & 0.654 & 0.602 \\
T3-T1+(tre-1.5mM) & 0.451 & 0.631 & 0.642 & 0.636 & 0.661 & 0.636 \\
T4- at 35 ${ }^{\circ} \mathrm{C}$ & 0.590 & 0.546 & 0.588 & 0.566 & 0.600 & 0.532 \\
T5-T4+(tre-1mM) & 0.596 & 0.546 & 0.591 & 0.566 & 0.616 & 0.538 \\
T6-T4+(tre-1.5mM) & 0.598 & 0.548 & 0.596 & 0.571 & 0.617 & 0.542 \\
T7- at 40 ${ }^{\circ} \mathrm{C}$ & 0.538 & 0.510 & 0.536 & 0.518 & 0.586 & 0.506 \\
T8-T7+(tre-1mM) & 0.548 & 0.516 & 0.568 & 0.532 & 0.588 & 0.516 \\
T9-T7+(tre-1.5mM) & 0.551 & 0.518 & 0.572 & 0.549 & 0.589 & 0.526 \\
CD 5\% & & & $\mathrm{V}=0.042, \mathrm{~T}=0.051, \mathrm{~V} \times \mathrm{T}=0.126$ & & \\
\hline
\end{tabular}

Table 3. Effect of trehalose on chlorophyll b (mg gm ${ }^{-1}$ fresh weight) content of wheat genotypes under heat stress (4hrs) of $35 \pm 2^{\circ} \mathrm{C}$ and $40 \pm 2^{\circ} \mathrm{C}$.

\begin{tabular}{lcccccc}
\hline \multirow{2}{*}{ Treatments } & \multicolumn{7}{c}{ Genotypes } \\
\cline { 2 - 7 } & HD2967 & PBW175 & C306 & PBW343 & PBW621 & PBW590 \\
\hline T1-Control at 25 ${ }^{\circ} \mathrm{C}$ & 0.415 & 0.404 & 0.413 & 0.405 & 0.432 & 0.312 \\
T2-T1+(tre-1mM) & 0.416 & 0.406 & 0.414 & 0.406 & 0.433 & 0.318 \\
T3-T1+(tre-1.5mM) & 0.417 & 0.406 & 0.415 & 0.406 & 0.439 & 0.332 \\
T4- at 35 ${ }^{\circ} \mathrm{C}$ & 0.400 & 0.359 & 0.398 & 0.398 & 0.406 & 0.312 \\
T5-T4+(tre-1mM) & 0.400 & 0.386 & 0.399 & 0.398 & 0.406 & 0.313 \\
T6-T4+(tre-1.5mM) & 0.401 & 0.400 & 0.399 & 0.398 & 0.408 & 0.313 \\
T7- at 40 ${ }^{\circ} \mathrm{C}$ & 0.358 & 0.315 & 0.354 & 0.341 & 0.370 & 0.306 \\
T8-T7+(tre-1mM) & 0.358 & 0.318 & 0.359 & 0.342 & 0.381 & 0.309 \\
T9-T7+(tre-1.5mM) & 0.359 & 0.335 & 0.360 & 0.346 & 0.385 & 0.311 \\
CD 5\% & & $\mathrm{V}=0.042, \mathrm{~T}=0.052, \mathrm{~V} \times \mathrm{T}=0.127$ & \\
\hline
\end{tabular}

Table 4. Effect of trehalose on chlorophyll $\mathrm{b}\left(\mathrm{mg} \mathrm{gm}^{-1}\right.$ fresh weight) content of wheat genotypes under heat stress $(8 \mathrm{hrs})$ of $35 \pm 2^{\circ} \mathrm{C}$ and $40 \pm 2^{\circ} \mathrm{C}$.

\begin{tabular}{lcccccc}
\hline \multirow{2}{*}{ Treatments } & \multicolumn{7}{c}{ Genotypes } \\
\cline { 2 - 7 } & HD2967 & PBW175 & C306 & PBW343 & PBW621 & PBW590 \\
\hline T1-Control at 25 ${ }^{\circ} \mathrm{C}$ & 0.418 & 0.402 & 0.410 & 0.406 & 0.432 & 0.330 \\
T2-T1+(tre-1mM) & 0.418 & 0.412 & 0.411 & 0.407 & 0.433 & 0.330 \\
T3-T1+(tre-1.5mM) & 0.419 & 0.413 & 0.412 & 0.407 & 0.433 & 0.331 \\
T4- at 35 ${ }^{\circ} \mathrm{C}$ & 0.361 & 0.316 & 0.343 & 0.342 & 0.370 & 0.296 \\
T5-T4+(tre-1mM) & 0.376 & 0.318 & 0.346 & 0.348 & 0.371 & 0.303 \\
T6-T4+(tre-1.5mM) & 0.376 & 0.349 & 0.348 & 0.356 & 0.372 & 0.326 \\
T7- at 40 ${ }^{\circ} \mathrm{C}$ & 0.306 & 0.296 & 0.298 & 0.296 & 0.306 & 0.217 \\
T8-T7+(tre-1mM) & 0.307 & 0.297 & 0.298 & 0.296 & 0.316 & 0.218 \\
T9-T7+(tre-1.5mM) & 0.307 & 0.297 & 0.299 & 0.297 & 0.317 & 0.276 \\
CD 5\% & & \multicolumn{7}{c}{$\mathrm{V}=0.0023, \mathrm{~T}=0.0029, \mathrm{~V} \times \mathrm{T}=0.0071$} \\
\hline
\end{tabular}

the fluidity of the thylakoid membranes (Larkindale et al., 2004).

In the present study it was also recorded that the application of trehalose increased the chlorophyll content in all genotypes. The application of higher concentration $(1.5 \mathrm{mM})$ of trehalose showed more increase in chlorophyll content as compare to $1 \mathrm{mM}$ of trehalose. Similar finding of Benaroudj et al., 2001 also pointed out that trehalose accumulation during heat stress protects the cells and cellular proteins of Saccharomyces cerevisiae from damage by oxygen radicals. During heat stress, trehalose pretreatment protects the ultrastructure of chloroplasts some polypeptides in thylakoid membranes, and also improves the photosynthetic capacity of thylakoids, which indicates a protective role of trehalose or its metabolite for the thylakoid membrane.
Carotenoid content: Heat stress decreased the carotenoid content in all the selected wheat genotypes (Table 7 and 8). The carotenoid content recorded between 0.0291 to 0.0298 . The maximum carotenoid content was recorded in HD2967 and minimum was observed in PBW175 genotype. In all the genotypes it was recorded that the carotenoid content showed maximum value at $25 \pm 2{ }^{\circ} \mathrm{C}$ as compared to moderate and severe heat stress. It was found all the genotypes showed increase in carotenoid content with the application of Trehalose. The concentration of $1 \mathrm{mM}$ of Trehalose showed increase in PBW621 and PBW590 under control conditions, whereas the concentration of $1.5 \mathrm{mM}$ of trehalose showed increase in carotenoid content in all the selected genotypes both in control and heat stressed conditions. The heat stress of $40 \pm 2^{\circ} \mathrm{C}$ (severe heat 
Aparjot Kaur and S.K. Thind / J. Appl. \& Nat. Sci. 9 (3): 1598 -1602 (2017)

Table 5. Effect of trehalose on total chlorophyll ( $\mathrm{mg} \mathrm{gm}^{-1}$ fresh weight) content of wheat genotypes under heat stress (4hrs) of $35 \pm 2^{\circ} \mathrm{C}$ and $40 \pm 2^{\circ} \mathrm{C}$.

\begin{tabular}{lcccccc}
\hline \multirow{2}{*}{ Treatments } & \multicolumn{7}{c}{ Genotypes } \\
\cline { 2 - 7 } & HD2967 & PBW175 & C306 & PBW343 & PBW621 & PBW590 \\
\hline T1-Control at 25 ${ }^{\circ} \mathrm{C}$ & 1.055 & 1.036 & 1.049 & 1.049 & 1.059 & 0.938 \\
T2-T1+(tre-1mM) & 1.056 & 1.037 & 1.049 & 1.049 & 1.059 & 0.941 \\
T3-T1+(tre-1.5mM) & 1.058 & 1.038 & 1.049 & 1.051 & 1.069 & 0.943 \\
T4- at 35 ${ }^{\circ} \mathrm{C}$ & 0.916 & 0.906 & 0.930 & 0.936 & 0.940 & 0.836 \\
T5-T4+(tre-1mM) & 0.917 & 0.906 & 0.939 & 0.936 & 0.941 & 0.838 \\
T6-T4+(tre-1.5mM) & 0.918 & 0.907 & 0.942 & 0.937 & 0.942 & 0.839 \\
T7- at 40 ${ }^{\circ} \mathrm{C}$ & 0.736 & 0.846 & 0.746 & 0.741 & 0.726 & 0.696 \\
T8-T7+(tre-1mM) & 0.736 & 0.847 & 0.746 & 0.742 & 0.727 & 0.697 \\
T9-T7+(tre-1.5mM) & 0.737 & 0.848 & 0.747 & 0.743 & 0.727 & 0.699 \\
CD 5\% & & $\mathrm{V}=0.0114, \mathrm{~T}=0.0140, \mathrm{~V} \times \mathrm{T}=0.0344$ & \\
\hline
\end{tabular}

Table 6. Effect of trehalose on total chlorophyll ( $\mathrm{mg} \mathrm{gm}^{-1}$ fresh weight) content of wheat genotypes under heat stress (8hrs) of $35 \pm 2^{\circ} \mathrm{C}$ and $40 \pm 2^{\circ} \mathrm{C}$.

\begin{tabular}{lcccccc}
\hline \multirow{2}{*}{ Treatments } & \multicolumn{7}{c}{ Genotypes } \\
\cline { 2 - 7 } & HD2967 & PBW175 & C306 & PBW343 & PBW621 & PBW590 \\
\hline T1-Control at 25 ${ }^{\circ} \mathrm{C}$ & 1.046 & 1.038 & 1.042 & 1.038 & 1.056 & 0.941 \\
T2-T1+(tre-1mM) & 1.049 & 1.038 & 1.041 & 1.038 & 1.057 & 0.941 \\
T3-T1+(tre-1.5mM) & 1.049 & 1.039 & 1.047 & 1.038 & 1.058 & 0.942 \\
T4- at 35 ${ }^{\circ} \mathrm{C}$ & 0.841 & 0.846 & 0.846 & 0.900 & 0.896 & 0.806 \\
T5-T4+(tre-1mM) & 0.842 & 0.847 & 0.847 & 0.918 & 0.897 & 0.807 \\
T6-T4+(tre-1.5mM) & 0.843 & 0.848 & 0.848 & 0.939 & 0.899 & 0.808 \\
T7- at 40 ${ }^{\circ} \mathrm{C}$ & 0.696 & 0.636 & 0.626 & 0.641 & 0.730 & 0.616 \\
T8-T7+(tre-1mM) & 0.697 & 0.637 & 0.627 & 0.642 & 0.734 & 0.616 \\
T9-T7+(tre-1.5mM) & 0.698 & 0.638 & 0.628 & 0.643 & 0.736 & 0.617 \\
CD 5\% & & $\mathrm{V}=0.0152, \mathrm{~T}=0.0187, \mathrm{~V} \times \mathrm{T}=0.0458$ & & \\
\hline
\end{tabular}

Table 7. Effect of trehalose on carotenoid ( $\mathrm{mg} \mathrm{gm}^{-1}$ fresh weight) content of wheat genotypes under heat stress $(4 \mathrm{hrs})$ of $35 \pm 2^{\circ} \mathrm{C}$ and $40 \pm 2{ }^{\circ} \mathrm{C}$.

\begin{tabular}{lcccccc}
\hline \multirow{2}{*}{ Treatments } & \multicolumn{7}{c}{ Genotypes } \\
\cline { 2 - 6 } & HD2967 & PBW175 & C306 & PBW343 & PBW621 & PBW590 \\
\hline T1-Control at 25 ${ }^{\circ} \mathrm{C}$ & 0.0298 & 0.0291 & 0.0295 & 0.0296 & 0.0293 & 0.0294 \\
T2-T1+(tre-1mM) & 0.0298 & 0.0291 & 0.0295 & 0.0296 & 0.0294 & 0.0295 \\
T3-T1+(tre-1.5mM) & 0.0299 & 0.0293 & 0.0296 & 0.0297 & 0.0296 & 0.0297 \\
T4- at 35 ${ }^{\circ} \mathrm{C}$ & 0.0280 & 0.0282 & 0.0276 & 0.0278 & 0.0279 & 0.0276 \\
T5-T4+(tre-1mM) & 0.0281 & 0.0281 & 0.0283 & 0.0278 & 0.0281 & 0.0283 \\
T6-T4+(tre-1.5mM) & 0.0282 & 0.0282 & 0.0281 & 0.0279 & 0.0282 & 0.0284 \\
T7- at 40 ${ }^{\circ} \mathrm{C}$ & 0.0253 & 0.0255 & 0.0251 & 0.0248 & 0.0264 & 0.0265 \\
T8-T7+(tre-1mM) & 0.0271 & 0.0269 & 0.0264 & 0.0262 & 0.0265 & 0.0266 \\
T9-T7+(tre-1.5mM) & 0.0272 & 0.0270 & 0.0265 & 0.0262 & 0.0266 & 0.0268 \\
CD 5\% & & \multicolumn{7}{c}{$\mathrm{V}=0.00278, \mathrm{~T}=0.00341, \mathrm{~V} \times \mathrm{T}=0.00835$} \\
\hline
\end{tabular}

Table 8. Effect of trehalose on carotenoid $\left(\mathrm{mg} \mathrm{gm}^{-1}\right.$ fresh weight) content of wheat genotypes under heat stress $(8 \mathrm{hrs})$ of $35 \pm 2{ }^{\circ} \mathrm{C}$ and $40 \pm 2^{\circ} \mathrm{C}$.

\begin{tabular}{lcccccc}
\hline \multirow{2}{*}{ Treatments } & \multicolumn{7}{c}{ Genotypes } \\
\cline { 2 - 7 } & HD2967 & PBW175 & C306 & PBW343 & PBW621 & PBW590 \\
\hline T1-Control at $25^{\circ} \mathrm{C}$ & 0.0296 & 0.0293 & 0.0294 & 0.0295 & 0.0294 & 0.0295 \\
T2-T1+(tre-1mM) & 0.0296 & 0.0293 & 0.0294 & 0.0295 & 0.0294 & 0.0296 \\
T3-T1+(tre-1.5mM) & 0.0297 & 0.0295 & 0.0295 & 0.0296 & 0.0295 & 0.0297 \\
T4- at 35 ${ }^{\circ} \mathrm{C}$ & 0.0261 & 0.0262 & 0.0263 & 0.0270 & 0.0271 & 0.0268 \\
T5-T4+(tre-1mM) & 0.0261 & 0.0261 & 0.0263 & 0.0271 & 0.0272 & 0.0266 \\
T6-T4+(tre-1.5mM) & 0.0262 & 0.0262 & 0.0264 & 0.0272 & 0.0273 & 0.0267 \\
T7- at 40 ${ }^{\circ} \mathrm{C}$ & 0.0223 & 0.0225 & 0.0221 & 0.0218 & 0.0221 & 0.0218 \\
T8-T7+(tre-1mM) & 0.0223 & 0.0225 & 0.0222 & 0.0221 & 0.0221 & 0.0220 \\
T9-T7+(tre-1.5mM) & 0.0224 & 0.0226 & 0.0223 & 0.0221 & 0.0222 & 0.0228 \\
CD 5\% & & \multicolumn{7}{c}{$\mathrm{V}=0.00493, \mathrm{~T}=0.00604, \mathrm{~V} \times \mathrm{T}=0.01479$} & \\
\hline
\end{tabular}


stress) for longer duration i.e. $8 \mathrm{hrs}$ showed maximum carotenoid content decrease in all the genotypes.

The carotenoid content in leaf blade, awn and lemma were much lower after heat stress treatment than the control (Xu Xiao-Ling et al., 2001). In response to heat stress, chloroplasts in the mesophyll cells of grape plants became round in shape, the stroma lamellae became swollen and the content of vacuoles formed clumps, whilst the cristae were disrupted and mitochondria became empty (Zhang et al., 2005).

\section{Conclusion}

Presently, as the six wheat genotypes were subjected to moderate $\left(35 \pm 2^{\circ} \mathrm{C}\right)$ and severe $\left(40 \pm 2^{\circ} \mathrm{C}\right)$ heat stress conditions. It has been observed in all the genotypes that the heat stress resulted in loss of photosynthetic pigments. More chlorophyll and carotenoid loss occurred under the severe heat stress conditions as compared to control and moderate stress. The genotype HD2967 showed high chlorophyll content even under the severe heat stress for 8 hours of duration. On the other hand PBW 175 followed by HD2967 showed higher carotenoid content under severe heat stress for 8 hours duration. Now in the treatments with the exogenously applied trehalose, there were increase in chlorophyll (a, b and total) and carotenoid contents as the trehalose known to protect the biological membranes from degradation by stabilizing them. Thus, the present findings demonstrated that exogenous application of trehalose to wheat has considerable potential for maintenance of thyllakoid membrane stability (mechanism unknown) in order to maintain the chlorophyll and carotenoid content in all the six studied wheat seedlings growing under heat stress conditions.

\section{REFERENCES}

Ahmad, J. U. and Hassan, M. A. (2011). Evaluation of seedling proline content of wheat genotypes in relation to heat tolerance. Bangladesh Journal of Botany. 40(1):17-22

Altenbach, S. B., DuPont, F. M., Kothari, K. M., Chan, R., Johnson, E. L. and Lieu, D. (2003). Temperature, water and fertilizer influence the timing of key events during grain development in a US spring wheat. $J$ Cereal Sci, 37: 9-20

Benaroudj, N., Lee, D. H. and Goldberg, A. L. (2001). Trehalose accumulation during cellular stress protects cells and cellular proteins from damage by oxygen radicals. $J$ BiolChem, 276: 24261-67

Dupont, F. M., Hurkman, W. J., Vensel, W. H., Tanaka, C., Kothari, K. M., Chung, O. K. and Altenbach, S. B. (2006). Protein accumulation and compo- sition in wheat grains: Effects of mineral nutrients and high temperature. Eur J Agron, 25: 96-107

FAO (2016). Food outlook biannual report on global food markets, Food and Agriculture Organization of United Nations

Gautam, A., Prasand, S. V. S., Ambati, D., Agarwal, D, and
Jajoo, A. (2016). Performance of durum wheat genotypes under drought and terminal heat stress conditions in changing climatic conditions. Res \& Review: $J$ Botanical Sciences, 5:4-5

Gomez, M. L. And Lluch, C. (2011). Trehalose and abiotic stress tolerance. Abiotic stress responses in plants, 24:253-65

Hiscox, J. D. and Israelstam, G. F. (1979). A method for the extraction of chlorophyll from leaf tissue without maceration. Can J Bot, 57: 1332-34

Khan, M. I., Mohammad, T., Subhan, F., Amin, M. and Shah, S. T. (2007). Agronomic evaluation of different bread wheat (TriticumaestivumL.) genotypes for terminal heat stress. Pak J Bot,39(7):2415-25

Khan, S. U., Din, J. U., Qayyum, A., Jan, N. E. And Jenks, M. A. (2015). Heat tolerance indicators in Pakistani wheat (TriticumaestivumL.) genotypes. Acta Bot. Croat., 74(1):109-21

Komayama, K., Khatoon, M., Takenaka, D., Horie, J., Yamashita, A., Yoshioka, M., Nakayama, Y., Yoshida, M., Ohira, S., Morita, N., Velitchkova, M., Enami, I. and Yamamoto, Y. (2007). Quality control of photosystem II: cleavage and aggregation of heat-damaged D1 protein in spinach thylakoids. Biochimbiophys Acta, 1767: 838-46

Kumar, R. R., Goswami, S., Sharma, S. K., Singh, K., Gadpayle, K. A. and Kumar, N. (2012). Protection against heat stress in wheat involves change in cell membrane stability, antioxidant enzyme, osmolyte, $\mathrm{H} 2 \mathrm{O} 2$ and transcript of heat shock protein. International Journal of Plant Physiology. Biochemical.4(4):83-91

Larkindale, J. and Huang, B. (2004). Changes of lipid composition and saturation level in leaves and roots for heat -stressed and heat acclimated creeping bentgrass (Agrostis stolonifera). Environ Exp Bot, 51: 57-67

Losa, D. A. and Murata, N. (2004). Membrane fluidity and its roles in the perception of environmental signals. Biochimbiophys Acta, 1666:142-57

NPCS (2012): Niir Project Consultancy Service A1 Books.co.in. Select and start your own industry. Pp 448

Shirdelmoghanloo, H., Cozzolino, D., Lohraseb, I, and Collins, N. C. (2016). Truncation of grain filling in wheat (Triticum aestivum) triggered by brief heat stress during early filling: association with senescence responces and reduction in stem reserves. Func Plant Bio 43: 919-30

Wahid, A., Gelani, S., Ashraf, M. and Foolad, M. R. (2007). Heat tolerance in plants: A overview. Envron and Expt Bot, 61: 199-223

Wardlaw, I. F., Blumenthal, C., Larroque, O. and Wrigley, C. (2002). Contrasting effects of heat stress and heat shock on kernel weight and flour quality in wheat. Funct Plant Biol, 29:25-34

Xu, X. L., Wang, Z. M. and Zhang, J. P. (2001). Effect of heat stress on photosynthetic characteristics of different green organs of winter wheat during grain filling stage. Acta Botanica Sinica, 43(6): 571-77

Zhang, J. H., Huang, W. D., Liu, Y. P. and Pan, Q. H. (2005). Effects of temperature acclimation pretreatment on the ultrastructure of mesophyll cells in young grape plants (Vitis vinifera L. Cv. Jingxiu) under cross- temperature stresses. J Integr. Plant Biol, 47: 959-70 